\title{
Spawane złącza doczołowe w mostach kolejowych w świetle kryterium Przydatności Użytkowej Konstrukcji
}

\author{
Welded butt joints in railway bridges according \\ to Fitness for Purpose
}

\section{Streszczenie}

Badania rentgenograficzne 155 mostów kolejowych, wybudowanych w latach 1936-1975, wykazały w ich spawanych złączach doczołowych występowanie niezgodności spawalniczych niedopuszczalnych przez normy odbioru. Dla spoin z pęknięciami wewnętrznymi określono ich wytrzymałość zmęczeniową. Analiza takich spoin w mostach na linii Katowice - Tczew wykazała, że są one w stanie bezpiecznie przenosić obciążenia eksploatacyjne. Przy ich analizie zastosowano kryterium Przydatności Użytkowej Konstrukcji.

Słowa kluczowe: mosty stalowe; złącza spawane; niezgodności spawalnicze

\begin{abstract}
X-ray studies of 155 railway bridges, built between 19361975 , showed in their welded butt joints occurrence of weIding imperfections unacceptable by the standards of reception. For welds with internal cracks the fatigue strength was determined. Analysis of such joints in bridges on the line Katowice - Tczew showed that they are able to carry the load safely during use. For their analysis the criterion of Fitness for Purpose was applied.
\end{abstract}

Keywords: steel bridges; fusion-welded joints; imperfections

\section{Wstęp}

Pomimo dużego postępu w zakresie materiałów i techniki spajania w ostatnich dekadach, pytanie: „czy złącze musi być najsłabszym miejscem konstrukcji?” jest nadal aktualne [1]. Szczególnie duże przemiany i postęp dokonuje się w zakresie zmierzającym do podniesienia jakości wytwarzanych połączeń $[2,3,4]$. Gwarantem wykonania konstrukcji stalowej o właściwej użytkowalności i trwałości jest zakład produkcyjny o odpowiednich uprawnieniach. Wykaz aktualnych wymagań spawalniczych dla danej klasy wykonania omówiono w pracy $[5,6]$. Niektórzy autorzy krytycznie oceniają nowowprowadzone poziomy jakości spoin zarówno pod względem spawalniczym oraz ekonomicznym i postulują problem ten poddać powszechnej dyskusji [3,4]. Pewnym przyczynkiem w tej dyskusji jest niniejszy artykuł. Wpływ niezgodności spawalniczych (NS), a w szczególności pęknięć w spoinach, należy rozpatrywać indywidualnie, biorąc pod uwagę krzywe wytrzymałości zmęczeniowej dla danej niezgodności i rozwiązania konstrukcyjne analizowanego złącza $[7,8]$. Należy wtedy zastosować kryteria Przydatności Użytkowej Konstrukcji (Fitness for Purpose), na podstawie których można ustalić czy NS jest dopuszczalna z punktu widzenia mechaniki pękania i rzeczywistego stanu obciążenia złącza $[9,10,11]$. Takie podejście do odbioru złączy spawanych, już od lat siedemdziesiątych XX wieku, jest stosowane w rurociągach gazowniczych oraz zbiornikach ciśnieniowych i zostało wprowadzone w kilku normach światowych omówionych w pracach $[9,10]$. Na rysunku 1 przedstawiono poziom dopuszczalności NS według wymagań norm i przepisów oraz wyznaczone na podstawie kryteriów Przydatności Użytkowej Konstrukcji (PUK), przy których konstrukcja ma wymagany zapas bezpieczeństwa. Konieczne jest wówczas zidentyfikowanie, metodami nieniszczącymi, wymiarów i położenia NS w złączu spawanym.

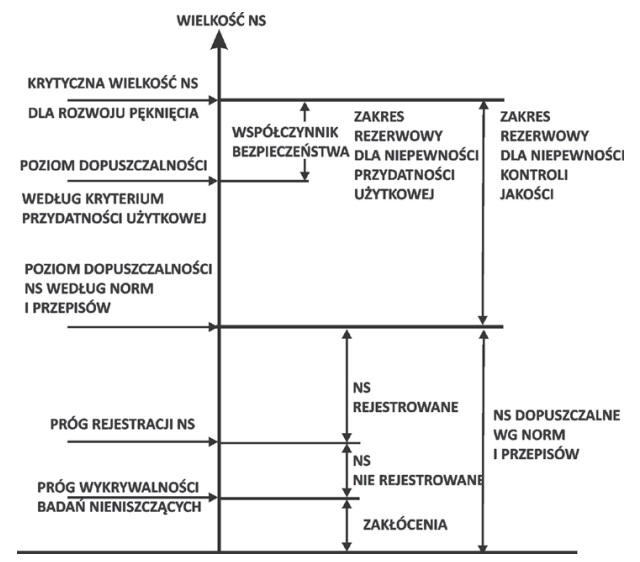

Rys. 1. Poziomy dopuszczalności niezgodności spawalniczych - NS według wymagań norm i przepisów oraz wg kryterium Przydatności Użytkowej Konstrukcji - PUK [9]

Fig. 1. The levels of acceptability of welding imperfections - according to the requirements of standards and regulations and according to the criterion of Fitness for Purpose - [9]

Dr hab. inż. Bernard Wichtowski, em. prof. ZUT - Zachodniopomorski Uniwersytet Technologiczny w Szczecinie.

Autor korespondencyjny/Corresponding author: marekw@zut.edu.pl 
Ustalenie wielkości wady krytycznej przeprowadza się według jednego z trzech poziomów jakości:

- pierwszy poziom jakości określony według najprostszych wzorów mechaniki pękania z wykorzystaniem przybliżonych danych o właściwościach materiału i naprężeniach,

- drugi poziom jakości bazujący na wzorach nieliniowej mechaniki pękania i dokładnych danych materiałowo-naprężeniowych,

- trzeci poziom jakości bazujący na obliczeniach jak w poziomie drugim z uwzględnieniem badań strukturalnych złącza.

Metodykę postępowania przy ustalaniu dopuszczalnych wielkości NS według danego poziomu jakości, wraz z modelami obliczeniowymi i przykładami obliczeń, przedstawiono obszernie w pracach $[9,10]$, a w odniesieniu do konstrukcji mostowej w pracy [12].

\section{Jakość złączy doczołowych w eksploato- wanych mostach kolejowych}

Słusznie stwierdzono $\mathrm{w}$ pracy [10], że prekursorem idei Przydatności Użytkowej Konstrukcji w Polsce był prof. Andrzej Fabiszewski $[13,14]$. To dzięki Profesorowi w ramach tematu Ministerstwa Komunikacji MK-133-06-02-04, który zamówiła Dyrekcja Generalna PKP, w latach 1954 - 1990 przeprowadzono badania rentgenograficzne spoin czołowych dźwigarów głównych około 200 eksploatowanych mostów kolejowych [15]. Dla 155 mostów, w tym 125 blachownicowych i 30 kratowych, ustalono dokładną datę ich budowy. Na rysunku 2 podano liczbę przebadanych mostów, wybudowanych w poszczególnych pięcioleciach oraz liczbę wykonanych rentgenogramów. Histogram górny obrazuje liczby mostów poddanych weryfikacji rentgenograficznej oraz liczby mostów, których dźwigary mają złącza doczołowe z pęknięciami. Histogram dolny przedstawia liczbę badanych złączy mostów wybudowanych w kolejnych pięcioleciach, poczynając od roku 1936, a kończąc na roku 1975.
Pęknięcia wykryto w 34 mostach $(21,9 \%)$ na 437 rentgenogramach. Stanowią one 2,8\% ogólnej liczby odcinków spoin badanych, równych 15875 rentgenogramów, z czego 10507 dotyczy złączy elementów rozciąganych, a pozostałe 5368 elementów ściskanych.

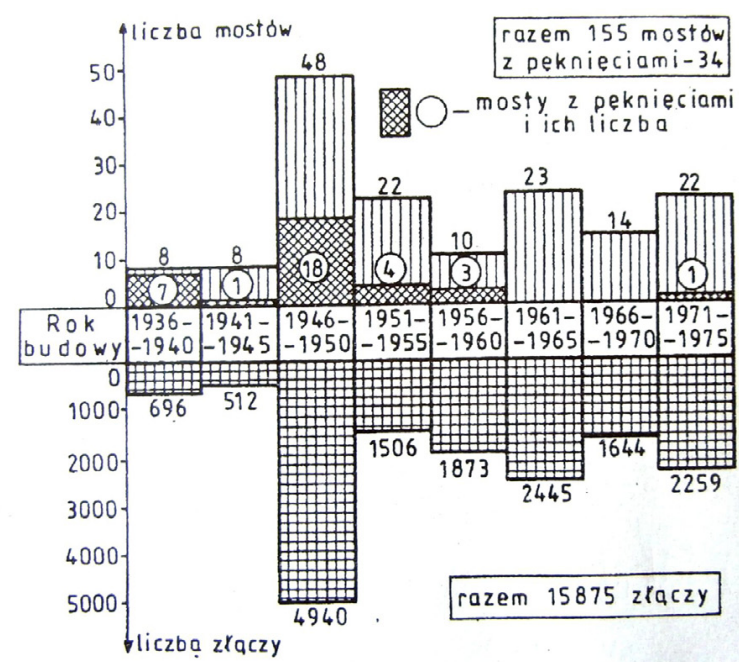

Rys. 2. Liczbowe zestawienie mostów i mostów z pęknięciami oraz badanych złączy spawanych

Fig. 2. Numerical collation of bridges, bridges with cracks and tested welded joints

Wykonane rentgenogramy spoin czołowych z badanych in situ mostów kolejowych zakwalifikowano do odpowiednich klas wadliwości od R1 do R5, zgodnie z wymogiem aktualnie obowiązującej w danym okresie normy PN-87/M-69772. W przybliżeniu klasy wadliwości $\mathrm{R} 1^{\sim} \mathrm{R} 5$ według tej normy są porównywalne z poziomem jakości spoin B+ D podanym w tabl. I według wymogów norm $[16,17]$.

Wielokrotne badania złączy doczołowych z pęknięciami wielu mostów, w interwałach czasowych $5 \sim 8$ letnich,

Tablica I. Podział liczbowy spoin poziomów jakości według PN-EN 1090-2 [16] i PN-EN ISO 5817 [17] oraz procentowy ich udział w sumie wykonanych rentgenogramów

Table I. Numerical segregation of quality levels of joints according to PN-EN 1090-2 [16] and PN-EN ISO 5817 [17], and percentage share in the total number of performed radiograms

\begin{tabular}{|c|c|c|c|c|c|c|c|c|c|}
\hline \multirow{3}{*}{$\begin{array}{c}\text { Poziom } \\
\text { jakości } \\
\text { spoin }\end{array}$} & \multicolumn{8}{|c|}{ Lata budowy mostów } & \multirow{3}{*}{$\frac{\sum r t g .}{\%}$} \\
\hline & $\begin{array}{l}1936- \\
-1940 \\
\end{array}$ & $\begin{array}{l}1941- \\
1945 \\
\end{array}$ & $\begin{array}{l}1946- \\
-1950 \\
\end{array}$ & $\begin{array}{l}1951- \\
-1955 \\
\end{array}$ & $\begin{array}{l}1956- \\
-1960 \\
\end{array}$ & $\begin{array}{r}1961- \\
-1965 \\
\end{array}$ & $\begin{array}{l}1966- \\
-1970 \\
\end{array}$ & $\begin{array}{l}1071- \\
-1975 \\
\end{array}$ & \\
\hline & \multicolumn{8}{|c|}{ Liczba rentgenogramów spoin } & \\
\hline $\mathrm{B}+$ & 56 & 198 & 660 & 557 & 1164 & 2039 & 1437 & 2062 & $\frac{8173}{51,5 \%}$ \\
\hline B & 53 & 88 & 627 & 380 & 393 & 294 & 156 & 140 & $\frac{2131}{13,4 \%}$ \\
\hline C & 97 & 89 & 734 & 240 & 119 & 89 & 46 & 34 & $\frac{1448}{9,1 \%}$ \\
\hline D & 90 & 34 & 493 & 69 & 40 & 9 & 4 & 19 & $\frac{758}{4,8 \%}$ \\
\hline$>\mathrm{D}$ & 400 & 103 & 2426 & 260 & 157 & 14 & 1 & 4 & $\frac{3365}{21,2 \%}$ \\
\hline Razem & 696 & 512 & 4940 & 1506 & 1873 & 2445 & 1644 & 2259 & $\frac{15875}{100 \%}$ \\
\hline
\end{tabular}


nie wykazały ich rozwoju ani powstawania nowych pęknięć. Obszerna próba wyjaśnienia tego zjawiska jest przedstawiona m.in. w pracy [8]. Widoczna „pewność" tych konstrukcji może być następstwem tego, że nie „pracowały” one jeszcze w okolicznościach niezbędnych do powstania uszkodzeń. Zakład Konstrukcji Metalowych PS, dokładną analizę tych okoliczności przeprowadził dla mostów trzech linii kolejowych: E20 Kunowice-Terespol, Centralnej Magistrali Kolejowej Warszawa-Katowice oraz magistrali węglowej Katowice-Tczew. W artykule analizę konstrukcyjno-naprężeniową ograniczono do badanych mostów usytuowanych na linii kolejowej Katowice-Tczew.

\section{Analiza badanych mostów na linii Katowice-Tczew}

Przekazanie do eksploatacji w 1933 r. linii KarszniceInowrocław umożliwiło wywóz węgla z zagłębia do Gdyni najkrótsza trasą Herby Nowe-Bydgoszcz-Gdynia. Budowa tej linii, zwanej magistralą węglową była największą inwestycją PKP w okresie międzywojennym. Obecnie jest to linia Katowice-Tczew długości 499 km. Na linii tej ZKM Politechniki Szczecińskiej prowadził w latach 1959-1974 kilkakrotnie badania rentgenograficzne spoin czołowych w 10 konstrukcjach mostowych usytuowanych zgodnie z rys. w tablicy II. Dziewięć konstrukcji mostowych zostało wykonanych w latach 1946 1949, a konstrukcja mostu nr X w 1965 roku. Konstrukcje nośną wszystkich mostów stanowią wolnopodparte dźwigary blachownicowe o rozpiętości teoretycznej od 10,9 m do $31,4 \mathrm{~m}$ (tabl. II). Badaniami rentgenograficznymi objęto poprzeczne spoiny czołowe pasów rozciąganych i ściskanych oraz środników dźwigarów głównych. Ogółem wykonano 1284 rentgenogramy spoin, w tym 658 zdjęć dotyczyło odcinków rozciąganych. Na rysunku 3 przedstawiono graficznie, w ujęciu procentowym i liczbowym, zestawienie przebadanych złączy doczołowych w poszczególnym moście z podziałem na poziomy jakości dopuszczalne (histogram górny) i niedopuszczalne (histogram dolny) według wymogów normy [16]. Na 10 rentgenogramach w 6 mostach stwierdzono pęknięcia spoin. Łącznie wykryto 12 pęknięć o długości od 8 do $90 \mathrm{~mm}$. W celu oszacowania trwałości użytkowej badanych mostów przeprowadzono analizę naprężeń w złączach doczołowych z pęknięciami, które stwierdzono w 6 mostach. Wyniki analizy podano w tablicy III. Dokonano obliczenia wartości naprężeń charakterystycznych występujących w spoinach czołowych (w osi nakładek i przykładek) oraz poza nakładkami w blasze pasowej lub środnika (wartości w mianowniku).

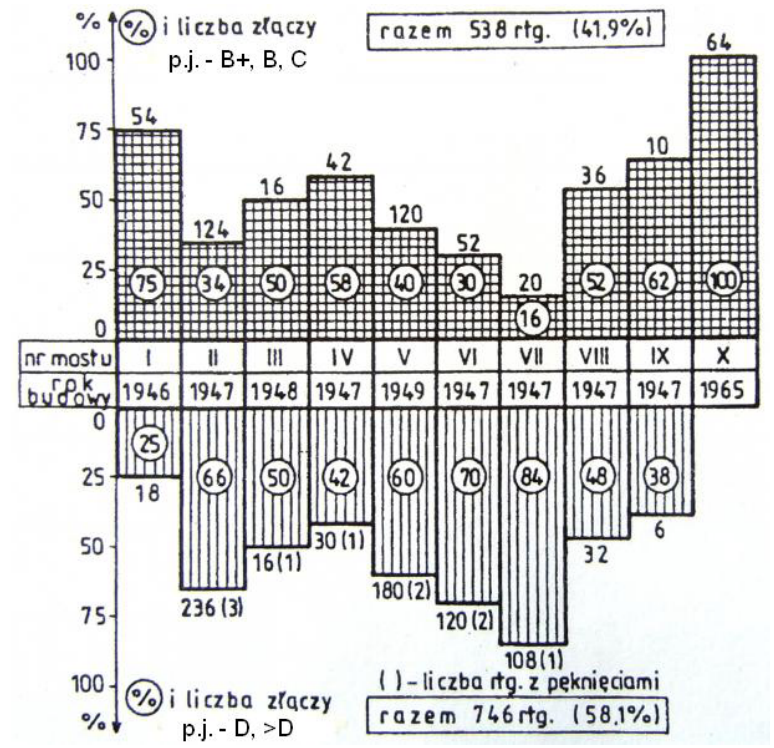

Rys. 3. Procentowe i liczbowe zestawienie niezgodności spoin badanych mostów według kryteriów akceptacji normy [16]

Fig. 3. Percentage and numerical collation of welded joints imperfections of tested bridges according to the acceptance criteria of the standard [16]

Tablica II. Usytuowanie badanych mostów i schematy ich dźwigarów nośnych Table II. Location of tested bridges and the diagrams of their carrying girders

Usytuowanie mostów




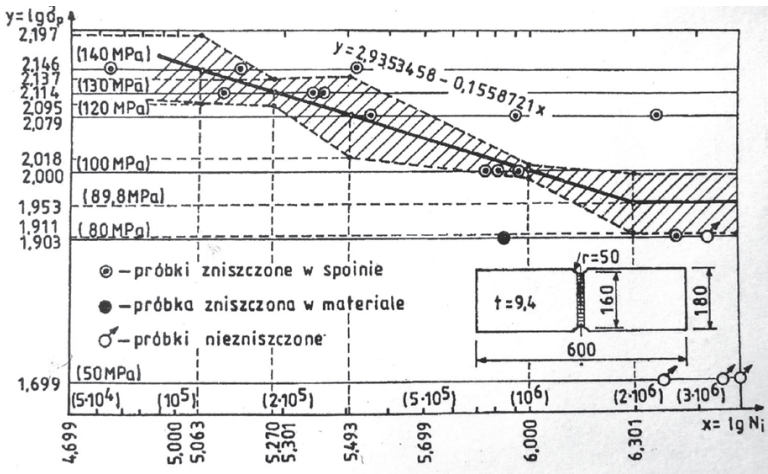

Rys. 4. Prosta regresji z obszarem ufności i wyniki badań zmęczeniowych 18 próbek

Fig. 4. Regression line with the confidence region and fatigue test results of 18 samples

Obliczenia wykonano zgodnie z PN-82/S-10052 i PN85/S-10030 - jak przy sprawdzaniu na zmęczenie, tj. przy obciążeniach charakterystycznych ze współczynnikiem dynamicznym. W kolumnie 3 podano wartość naprężeń nominalnych od stałego obciążenia mostu, a w kol. 4 od obciążenia stałego i obciążeń normowych taborem, z uwzględnieniem wpływów dynamicznych. Naprężenia te wyznaczono od podstawowego układu obciążeń, przyjmując klasę obciążenia $\mathrm{k}=$ +2. W kolumnie 5 zestawiono wartości naprężeń od obciążenia stałego i ruchomego lokomotywą ET-21, z uwzględnieniem wpływów dynamicznych. Natomiast w kolumnie 6 podano sumę naprężeń od obciążenia stałego i pomierzonych tensometrycznie wartości naprężeń w pasowych stykach doczołowych mostu przez rzekę Ner (most nr V). Naprężenia mierzono w trakcie przejazdów pociągów towarowych z parowozami typu TY 246 lub TY 51. W kolumnie 7 podano stosunek naprężeń $\sigma_{\text {ekspl }} / \sigma_{\text {norm }}$ a w kol. 8 przypuszczalną liczbę przejeżdżających pociągów do 2000 r. przez jeden tor na danym moście.

\section{Badania zmęczeniowe złączy z pęknięciami wewnętrznymi}

W ramach kompleksowej oceny żywotności złączy z pęknięciami wewnętrznymi przeprowadzono ich laboratoryjne badania zmęczeniowe. Technologię wykonywania próbek i metodykę przeprowadzania badań przedstawiono w pracy [7]

Spoiny spawano ręcznie w pozycji podolnej, elektrodami kwaśnymi EA1.46 o średnicy 4,0 mm przy prądzie stałym o biegunowości ujemnej i natężeniu 180 200A. Badania rentgenograficzne 18 próbek (rys. 4) wykazały, poza pęknięciami o długościach od 14 do $145 \mathrm{~mm}$, istnienie pęcherzy gazowych i żużli zwartych, a w dwóch przypadkach żużli pasmowych oraz odcinkowego braku przetopu. Badania zaprogramowano zgodnie $\mathrm{z}$ wymogiem $\mathrm{PN}-76 / \mathrm{H}-04325$, stosując jednostronne, cykliczne rozciąganie na sześciu poziomach naprężeń nominalnych: 140, 130, 120, 100, 80 i 50 MPa, przy współczynniku amplitudy $R=0,1$. Badania przeprowadzono na pulsatorze z częstotliwością 300 cykli na minutę, a parametry zniszczenia poszczególnych próbek przedstawiono na rysunku 4. Tam też podano wyznaczone równanie prostej regresji, w układzie logarytmicznym, z którego wyznaczona wartość nieograniczonej wytrzymałości na zmęczenie wynosi $Z_{\mathrm{rj}}=89,8 \mathrm{MPa}$, dla $\mathrm{N}_{\mathrm{i}}=2 \cdot 10^{6}$ cykli obciążenia.

Tablica III. Naprężenia normalne w spoinach czołowych z pęknięciami (wartości w liczniku) oraz poza nakładkami (wartości w mianowniku), stosunek naprężeń eksploatacyjnych do normowych i liczba cykli obciążenia mostu

Table III. Normal stresses in butt welds with cracks (values in the numerator) and outside cover plates (values in the denominator), the ratio of usable stresses to the standard ones and number of load bridge cycles

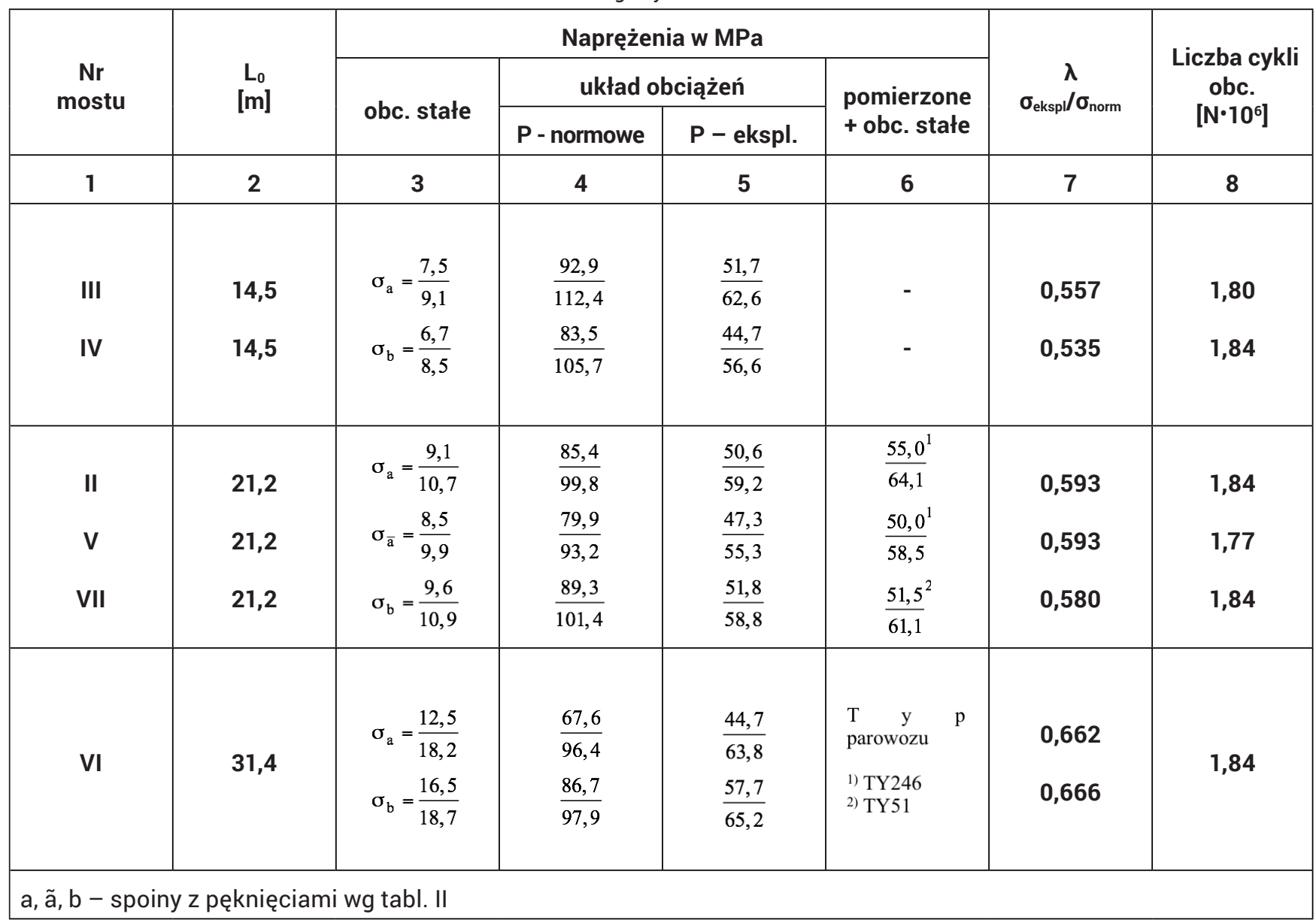




\section{Podsumowanie}

Przedstawione badania rentgenograficzne pozwoliły zewidencjonować niezgodności spawalnicze złączy doczołowych w dźwigarach głównych 155 mostów kolejowych. Szczególnie dużą liczbę spoin z istotnymi NS stwierdzono w obiektach wybudowanych do roku 1960. $37,5 \%$ badanych mostów z tego okresu ma pęknięcia wewnętrzne w spoinach czołowych.

Określona z badań laboratoryjnych, nieograniczona wytrzymałość zmęczeniowa spoin czołowych z pęknięciami wewnętrznymi $Z_{\mathrm{rj}}=90 \mathrm{MPa}$ jest każdorazowo większa od wartości naprężeń rozciągających wyznaczonych od obciążenia eksploatacyjnego w tego typu spoinach mostowych $\sigma=52 \sim 58 \mathrm{MPa}$.

W złączach spawanych konstrukcji, płaskie niezgodności spawalnicze takie jak pęknięcia, przyklejenia oraz braki przetopu mogą występować wewnątrz złącza, jeżeli naprężenie inicjujące pęknięcie będzie mniejsze od naprężenia koniecznego do jego rozwoju [7,8]. Stwierdzenie to potwierdziły obliczenia trwałości, jednego z badanych mostów mającego pęknięcia w złączach doczołowych, powstałe w 1936 roku [12]. Fakty te stanowią materiał weryfikujący już zastosowanych nowych metod w ocenie mostów istniejących, przez normy Kanady, Wielkiej Brytanii, Danii i Szwajcarii. W normach tych państw przyjęto częściowo kryteria PUK [18].

\section{Literatura}

[1] Senkara J.: Czy złącze musi być najsłabszym miejscem konstrukcji ? Biuletyn Instytutu Spawalnictwa w Gliwicach, nr 5/2003.

[2] Ferenc K., Ferenc J.: Współczesne technologie spawania i kontrola jakości konstrukcji budowlanych. XIX Ogólnopolska Konferencja Warsztat Pracy Projektanta Konstrukcji, Ustroń 2004.

[3] Czuchryj J., Sikora S. Staniszewski K.: Ocena jakości złączy spawanych w konstrukcjach kontrolowanych radiograficzne na podstawie poziomu jakości B+ wg PN-EN 1090-2. Przegląd Spawalnictwa, nr 3/2013.

[4] Wichtowski B: W sprawie nowych wymagań jakościowych dotyczących połączeń spawanych w mostach stalowych, Inżynieria i Budownictwo, nr 5/2015.

[5] Hołowaty, J., Wichtowski B.: Testing of Welded Joints in Steel Bridges to European Standards, Steel Bridges: Innovation \& New Challenges 2015. International Symposium, Istambul 2015

[6] Wichtowski B., Hołowaty J.: Badania złączy spawanych w mostach stalowych według wymagań norm PN-EN 1090-2 i PN-EN ISO 5917. Inżynieria i Budownictwo, $3 / 2016$

[7] Wichtowski B.: Wytrzymałość zmęczeniowa spawanych złączy doczołowych w stalowych mostach kolejowych. Prace Naukowe PS nr 572, Szczecin 2002.

[8] Kocanda S.: Zmęczeniowe pękanie metali. WNT, Warszawa 1985.

[9] Klimpel A.: Kontrola i zapewnienie jakości w spawalnictwie, tom. 1. Wydawnictwo Politechniki Śląskiej, Gliwice 1998.

[10] Rykaluk K. Pęknięcia w konstrukcjach stalowych. DWE, Wrocław 1999.
[11] Fisher J.W., Mertz D.R.: Hundreds of bridges - thousands of cracks. Civil Engineering (ASCE), No 4, 1985.

[12] Rykaluk K., Wichtowski B.: Wytrzymałość konstrukcji mostowej z pęknięciami w spawanych złączach czołowych. Materiały XLIII Konferencji Naukowej KILiW PAN i KN PZITB, t.5, Krynica-Poznań 1997.

[13] Fabiszewski A.: Dotychczasowe badania rentgenograficzne konstrukcji mostowych. Zeszyty Naukowe Politechniki Szczecińskiej Nr 6, Technika z.4, PWN, Poznań 1958.

[14] Fabiszewski A.: Warunki naprężeniowe powstawania kruchych pęknięć w konstrukcjach stalowych pod wpływem wad spawalniczych. Zeszyty Naukowe Politechniki Szczecińskiej Nr 29, Prace Monograficzne nr 4, Szczecin 1962.

[15] Ostapiuk H., Wichtowski B.: Stan złączy spawanych w eksploatowanych mostach kolejowych w świetle badań rentgenograficznych. Inżynieria i Budownictwo, $\mathrm{nr}$ 10/1991.

[16] PN-EN 1090-2 + A1:2012 Wykonanie konstrukcji stalowych i aluminiowych Część 2: Wymagania techniczne dotyczące konstrukcji stalowych.

[17] PN-EN ISO 5817:2014 Spawanie-Złącza spawane ze stali, niklu, tytanu i ich stopów (z wyjątkiem spawanych wiązką) - Poziomy jakości według niezgodności spawalniczych.

[18] Wiśniewski D., Majka M., Bień J.: Ocena nośności mostów w okresie ich eksploatacji - doświadczenia krajowe i zagraniczne. Inżynieria i Budownictwo, nr 7-8/2013. 